Received Date : 08-Nov-2016

Revised Date : 02-Jan-2017

Accepted Date : 19-Jan-2017

Article type : Original Article

\title{
Locus coeruleus at asymptomatic early and middle Braak stages of neurofibrillary tangle pathology
}

Pol Andrés-Benito, $\mathrm{MSc}^{1}$, Victor Fernández-Dueñas, $\mathrm{PhD}^{4,5}$, Margarita Carmona Margarita, Tech ${ }^{1}$, Luis Alberto Escobar, MD¹, Benjamín Torrejón-Escribano, $\mathrm{PhD}^{6}$, Ester Aso, $\mathrm{PhD}^{1,2}$, Francisco Ciruela, $\mathrm{PhD}^{4,5}$, Isidro Ferrer, $\mathrm{MD}, \mathrm{PhD}^{1,2,3,5, \mathrm{CA}}$

${ }^{1}$ Institut de Neuropatologia, Servei d'Anatomia Patològica, Hospital Universitari de Bellvitge, L'Hospitalet de Llobregat, Spain;

2Departament de Patologia i Terapèutica Experimental, Universitat de Barcelona, L'Hospitalet de Llobregat, Spain;

${ }^{3}$ CIBERNED, Centro de Investigación Biomédica en Red de Enfermedades Neurodegenerativas, Instituto de Salud Carlos III, Spain;

${ }^{4}$ Unitat de Farmacologia, Departament Patologia i Terapèutica Experimental, IDIBELL, Universitat de Barcelona, L'Hospitalet de Llobregat, Spain;

${ }^{5}$ Institut de Neurociències, Universitat de Barcelona, Spain;

6 Unitat de Biologia (BT-E), Serveis Cientifics I Tecnics, Universitat de Barcelona, L'Hospitalet de Llobregat, Spain

\section{Short title: Locus coeruleus at early stages of NFT pathology}

CA: Corresponding author:

Prof. Isidro Ferrer, Institute of Neuropathology, Service of Pathologic Anatomy, Bellvitge University Hospital, carrer Feixa Llarga sn, 08907 Hospitalet de Llobregat, Spain; Phone: +34 93 4035808; email: 8082ifa@gmail.com

This article has been accepted for publication and undergone full peer review but has not been through the copyediting, typesetting, pagination and proofreading process, which may lead to differences between this version and the Version of Record. Please cite this article as doi: 10.1111/nan.12386

This article is protected by copyright. All rights reserved. 


\section{Financial disclosure and conflict of interests}

No relevant data.

\section{Funding}

This study was funded by Ministerio de Economía y Competitividad, Instituto de Salud Carlos III - Fondos FEDER, a way to build Europe: FIS PIE14/00034 and PI14/00757 to IF, and IFI15/00035 fellowship to PA-B; it was also supported by MINECO (SAF2014-55700-P and PCIN-2013-019-C03-03) and AWT (SBO-140028) to FC.

\section{Abstract}

Aims: The present study analyzes molecular characteristics of the locus coeruleus (LC) and projections to the amygdala and hippocampus at asymptomatic early and middle Braak stages of neurofibrillary tangle (NFT) pathology.

Methods: Immunohistochemistry, whole transcriptome arrays and RT-qPCR in LC, and western blotting in hippocampus and amygdala in a cohort of asymptomatic individuals at stages I-IV of NFT pathology were used.

Results: NFTs in the LC increased in parallel with co-localized expression of tau-kinases; increased neuroketal adducts and decreased superoxide dismutase 1 in neurons with hyperphosphorylated tau, and decreased VDAC in neurons containing truncated tau were found. These were accompanied by increased microglia and AIF1, CD68, PTGS2, IL1 $\beta$, IL6 and $T N F-\alpha$ gene expression. Whole transcriptome arrays revealed up-regulation of genes coding for proteins associated with heat shock protein binding and genes associated with ATP metabolism; and down-regulation of genes coding for DNA-binding proteins and of members of the Small Nucleolar RNAs family, at stage IV when compared with stage I. Tyrosine hydroxylase $(\mathrm{TH})$ immunoreactivity was preserved in neurons of the LC, but decreased TH and increased $\alpha_{2 A}$ adrenergic receptor protein levels were found in the hippocampus and the amygdala.

Conclusions: Complex alteration of several metabolic pathways occurs in the LC accompanying NFT formation at early and middle asymptomatic stages of NFT pathology. Dopaminergic/noradrenergic denervation and increased expression of $\alpha_{2 A}$ adrenergic receptor in the hippocampus and amygdala occur at first stages of NFT pathology, suggesting compensatory activation in the face of decreased adrenergic input occurring before clinical evidence of cognitive impairment and depression.

Key words: Alzheimer's disease, locus coeruleus, amygdala, hippocampus, tau, tyrosine hydroxylase, $\alpha_{2 A}$ adrenergic receptor, mitochondria, transcriptome, heat shock proteins, protein metabolism, small nucleolar RNAs

This article is protected by copyright. All rights reserved. 


\section{Introduction}

Alzheimer's disease $(A D)$, the most common cause of cognitive impairment in the elderly, is a progressive neurodegenerative disorder lasting for decades which is characterized morphologically by accumulation of $\beta$-amyloid in the neuropil forming fibrillar diffuse deposits and senile plaques; $\beta$-amyloid deposits in blood vessels leading to amyloid angiopathy; and intraneuronal accumulation of hyper-phosphorylated and truncated 3Rtau and 4Rtau as the major component of neurofibrillary tangles (NFTs), neuropil threads, and dystrophic neurites of senile plaques [1-3].

These morphological alterations have a particular pattern of distribution which extends to most of the brain along with disease progression [4-7] paralleling the progressive appearance of clinical symptoms [8-10]. Clinical and pathological changes do not progress in the same way in all individuals; about $85 \%$ of the population aged 65 has brain lesions consistent with early changes of $A D$, yet only about $5 \%$ have reached thresholds leading to severe cognitive impairment and dementia (clinical stages of the neurodegenerative process) [11, 12]. However, $25 \%$ of the population at the age of 85 suffers from dementia of Alzheimer type [12].

The locus coeruleus (LC) is a pontine nucleus containing the largest group of noradrenergic neurons in the central nervous system $[13,14]$. While the rostral portion of the LC innervates mostly forebrain structures such as the hippocampus and cerebral cortex, the caudal portion innervates mainly hindbrain regions [15-18]. The LC is the only noradrenergic nucleus innervating the cerebral cortex [19] whereas the amygdala also receives projections from the lateral brainstem tegmentum [20]. The LC receives input from various regions of the brain [21]. All these neuronal networks display the LC as a hub nucleus implicated in superior functions such as arousal, attention, wake-sleep cycles, emotional states, cognition, memory and learning, regulation of blood flow, motor coordination, neuroinflammation, neuronal survival, and neurogenesis [14, 22-28].

Noradrenaline released from the LC acts at specific synapses through $\alpha_{1^{-}}, \alpha_{2}-$ or $\beta$ adrenoceptors [29, 30]. Activation of $\alpha_{1}$-adrenoceptors generally leads to excitation, and there is some evidence that $\beta$-adrenoceptors are also excitatory. In contrast, activation of $\alpha_{2}-$ adrenoceptors leads to inhibition, including inhibition of the noradrenergic neurons themselves through autoreceptors.

The LC is the main noradrenergic nucleus affected in AD [31]. Involvement of the LC at advanced stages of $A D$ has been recognized for decades [14, 32-37]. Considering a percentage of neuron loss of about $70 \%$ at terminal stages of the disease [33,36], it is conceivable that many functions regulated by the LC are severely dampened in advanced

This article is protected by copyright. All rights reserved. 
AD. However, the LC, together with raphe nuclei, is one the first regions of the brain showing NFTs in the context of AD-related pathology [38-42].

Based on this scenario, the present study was focused on the LC at the first asymptomatic Braak stages of NFT pathology in an attempt to 1: define characteristics of tau phosphorylation, configuration and truncation, associated expression of tau kinases, proteins involved in energy metabolism, oxidative stress and responses, tyrosine hydroxylase (TH) immunoreactivity, and local synapses in the LC; 2 : assess the impact of these alterations of the LC on the expression of noradrenergic receptors and $\mathrm{TH}$ in the hippocampus and amygdala; and 3: unveil altered gene expression to identify altered pathways in LC associated with early stages of NFT pathology using whole transcription arrays.

\section{Materials and methods \\ Human brain samples}

Human brain samples were obtained from the Institute of Neuropathology Brain Bank (HUBICO-IDIBELL biobank) following the guidelines of the Spanish legislation on this matter (Real Decreto Autorización y Funcionamiento de Biobancos, Ministry of Science and Innovation: 1716/2011) and the approval of the local ethics committee of the Bellvitge University Hospital-IDIBELL.

No individuals in the present series had neurological complaints; all of them were categorized as cognitively well preserved at the time of admission to the hospital; depression was not reflected in the clinical records of any case. All of them were admitted and died in the hospital from various non-neurological diseases. NFT pathology was an incidental observation during the post-mortem neuropathological study. However, it is worth stressing that clinical histories were not directed to exhaustively analyze 'minor' neurological and neuropsychological changes such as recent modifications in mood, wake-sleep cycle disturbances, impairment of attention, and learning capacity. Therefore, these symptoms might have been present without being recorded in some individuals.

Neuropathologic diagnosis was made following the Braak and Braak staging for NFTs adapted to paraffin sections [4, 43], Thal phases for $\beta$-amyloid score [5], and CERAD stages of senile plaques [44]. Cases with combined pathologies were excluded from the present study. Only cases with concomitant mild small vascular disease were accepted. Cases with evident long agonic state, hypoxia, or seizures were excluded.

Two series of cases were used. For morphological and immunohistochemical studies, categorization of cases was as follows: Braak stage I of NFT pathology: $n=21,10$ men, 11 women, age $66.7 \pm 6.68$ years; stage II: $n=19,12$ men, 7 women, age $70.3 \pm 7.83$ years;

This article is protected by copyright. All rights reserved. 
stage III: $n=15,5$ men, 10 women, age $77.6 \pm 6.83$; and stage IV, $n=12,8$ men, 4 women, age $77.75 \pm 8.01$ years. The post-mortem delay was $7.4 \pm 5.1$ hours (between $2 \mathrm{~h}$ and $21 \mathrm{~h}$ ). The purpose of the first series was to analyze changes linked to tau phosphorylation in LC; control cases without NFT pathology were not necessary.

The second series of cases was used for biochemical studies including whole transcriptome arrays and RT-qPCR validation in LC, and determination of protein levels of tyrosine hydroxylase $(\mathrm{TH})$ and $\alpha_{2 A}$ adrenergic receptor $\left(\alpha_{2 A}-A R\right)$ with western blotting in the hippocampus and amygdala. Each of these studies was carried out in all cases. Categorization of cases was as follows: middle-aged individuals with no clinical symptoms and without neuropathological lesions (no $\beta$-amyloid deposits, NFT stage 0 ) called MA: $n=$ 10, 6 men, 4 women, age $51.3 \pm 5.9$; stage $\mathrm{I}: \mathrm{n}=8,7$ men, 1 women, age $66.2 \pm 6.45$ years; stage II: $n=4,1$ men, 3 women, age $65.5 \pm 9.60$ years; stage III: $n=8,6$ men, 2 women, age $76.7 \pm 9.20$; and stage IV, $n=5,4$ men, 1 women, age $83.8 \pm 5.93$ years. The postmortem delay was $6.42 \pm 3.64$ hours (between $2 \mathrm{~h}$ and $14 \mathrm{~h}$ ) (Supplementary Table I). The purpose of the second series was to assess changes in LC at early and middle stages of NFT pathology compared with MA individuals with no NFT pathology used as controls. Thal phases varied from 0 to 1 and neuritic plaque score CERAD from 0 to 1 in cases with NFT pathology. $\beta$-amyloid deposits in LC were not found in any cases.

\section{Immunohistochemistry}

De-waxed sections, $4 \mu \mathrm{m}$ thick, of the LC were processed for immunohistochemistry. The sections were boiled in citrate buffer $(20 \mathrm{~min})$ to retrieve tau antigenicity. Endogenous peroxidases were blocked by incubation in $10 \%$ methanol- $1 \% \mathrm{H}_{2} \mathrm{O}_{2}$ solution (15 min) followed by $3 \%$ normal horse serum solution. Then the sections were incubated at $4^{\circ} \mathrm{C}$ overnight with one of the primary antibodies listed in Supplementary Table II. Following incubation with the primary antibody, the sections were incubated with EnVision + system peroxidase (Dako, DK) for $30 \mathrm{~min}$ at room temperature. The peroxidase reaction was visualized with diaminobenzidine and $\mathrm{H}_{2} \mathrm{O}_{2}$. Control of the immunostaining included omission of the primary antibody; no signal was obtained following incubation with only the secondary antibody.

\section{Double-labeling immunofluorescence and confocal microscopy}

De-waxed sections, 4 microns thick, were stained with a saturated solution of Sudan black B (Merck, DE) for 15 min to block the autofluorescence of lipofuscin granules present in cell bodies, and then rinsed in $70 \%$ ethanol and washed in distilled water. The sections were incubated at $4^{\circ} \mathrm{C}$ overnight with combinations of primary antibodies. After washing, the sections were incubated with Alexa488 or Alexa546 (1:400, Molecular Probes, US) fluorescence secondary antibodies against the corresponding host species. Nuclei were stained with DRAQ5 ${ }^{\mathrm{TM}}(1: 2,000$, Biostatus, GB). After washing, the sections were mounted 
in Immuno-Fluore mounting medium (ICN Biomedicals, US), sealed, and dried overnight. Sections were examined with a Leica TCS-SL confocal microscope.

\section{Quantification of morphological studies}

Quantification was carried out in the rostral part of the LC within the dorsolateral pontine tegmentum at the level of the lower segment of the cerebral aqueduct of Sylvius just before the IV ventricle [45]. Neurons with NFTs as revealed with the antibody AT8 were counted in all cases of the morphological series ( $n=67$ ), using three non-consecutive sections per case separated by 50 microns at a magnification of $x 200$; the total number of neurons was estimated in the same sections, which were slightly counterstained with haematoxylin. Unbiased stereological estimation of the total number of neurons [46] was not possible in the present series as tissue blocks did not contain the whole LC. However, this limitation had no substantial implications in the purposes at hand, as discussed below.

About 5,360 neurons were counted in total. Results were expressed as the percentage of neurons with NFTs in relation to the total number of LC neurons at stages I, II, III, and IV of NFT pathology. Mean values for each group were compared with one-way analysis of variance (ANOVA) followed by post-hoc Tukey's multiple comparison test, and differences were considered statistically significant at $p<0.05 ; p<0.01$; and $p<0.001$.

The estimation of co-localization of two proteins labeled with specific antibodies and examined with the confocal microscope was assessed by counting the number of cells expressing both antigens in relation to the number of cells stained with each one of the antibodies in five selected fields per section and three sections in every case. The number of cells counted varied depending on the size of the population bearing the most abundant assessed protein. The values were expressed as the percentage of the more abundant protein because the less abundant protein represented a subset of the former (i.e., percentage of P-tauThr181-positive neurons co-expressing Alz50).

\section{Total membrane preparation}

Frozen samples of the hippocampus and amygdala were homogenized in ice-cold $10 \mathrm{mM}$ Tris $\mathrm{HCl}, \mathrm{pH} 7.4,1 \mathrm{mM}$ EDTA, $300 \mathrm{mM} \mathrm{KCl}$ buffer containing a protease inhibitor cocktail (Roche Molecular Systems, USA) using a Polytron for three periods of $10 \mathrm{~s}$ each. The homogenate was centrifuged for $10 \mathrm{~min}$ at $1,000 \mathrm{xg}$. The resulting supernatant was centrifuged for $30 \mathrm{~min}$ at $12,000 \mathrm{xg}$. The membranes were dispersed in $50 \mathrm{mM}$ Tris $\mathrm{HCl}(\mathrm{pH}$ 7.4) and $10 \mathrm{mM} \mathrm{MgCl}_{2}$, washed, and re-suspended in the same medium as described previously [47]. Protein concentration was determined using the BCA protein assay kit (Thermo Fisher Scientific, Inc., Rockford, IL, USA) and $80 \mu \mathrm{g}$ of protein were used for Immunoblot. Plasmids and transfection used to verify the characteristics of $\alpha_{2 A}-A R$ expressed in HEK-293T cells are shown in Supplementary data 2.

This article is protected by copyright. All rights reserved. 


\section{Gel electrophoresis and immunoblotting}

Sodium dodecyl sulfate polyacrylamide gel electrophoresis (SDS/PAGE) was per- formed using $10 \%$ polyacrylamide gels. Proteins were transferred to PVDF membranes using a semidry transfer system and immunoblotted with the indicated antibody, and then with HRPconjugated rabbit anti-goat $(1: 30,000)$ or goat anti-rabbit $\lg (1: 30,000)$. The immunoreactive bands were developed using a chemiluminescent detection kit (Pierce) and the Amersham Imager 600 (GE Healthcare Europe GmbH, Barcelona, Spain).

\section{Whole-transcriptome arrays}

\section{Synthesis and hybridization of cRNA}

RNA from frozen LC was extracted following the instructions of the supplier (Rneasy Mini Kit, Qiagen ${ }^{\circledR} \mathrm{GmbH}$, Hilden, GE). RNA integrity number (RIN) and 28S/18S ratios were determined with the Agilent Bioanalyzer (Agilent Technologies Inc, Santa Clara, CA, USA) to assess RNA quality; RNA concentration was evaluated using a NanoDrop ${ }^{\mathrm{TM}}$ Spectrophotometer (Thermo Fisher Scientific, Carlsbad, CA, USA). RIN (RNA integrity number) values are presented in Supplementary Table I. Suitability of such cases for mRNA expression studies was tested by RT-qPCR using different probes. The outliers were detected using the GraphPad software QuickCalcs ( $p<0.05)$.

Details of microarray hybridization are shown in Supplementary data 3. The method of RNA sample preparation was based on the original T7 in vitro transcription technology known as the Eberwine or RT-IVT method [48].

\section{Microarray data analysis}

Microarray data quality control, normalization, and filtering were performed using Bioconductor packages in $\mathrm{R}$ programming environment for genes [49]. Processing of raw data for the non-coding regions was performed using Affymetrix Transcription Array Console software (Santa Clara, CA, USA). Cofactor neuritic plaques and gender ( $M$ or $W$ ) were considered in the analysis as well as the experimental batch (1 or 2). Genes were first selected based upon their experimental values using a test for differential expression between two classes (Student's t-test) or a clustering method for co-expressed genes (ANOVA one-way test). Genes were considered differentially expressed if they showed an absolute fold change $>1.2$ in combination with an unadjusted $p$-value $\leq 0.05$, as differentially expressed genes obtained from the microarray were lower than currently selected fold change values between 2.0 and 2.5 [50].

Microarray data post-analysis: Gene ontology (GO) and Ingenuity pathway analysis (IPA)

Once a list of differentially expressed genes was identified from microarrays, the selection of putative candidates was analyzed for biological significance using a gene enrichment analysis against Gene ontology (GO) through bioconductor packages in R programming

This article is protected by copyright. All rights reserved. 
using $p<0.05$ as the cut-off point to determine whether $\mathrm{GO}$ database was significantly enriched. The core analysis function included in IPA (Ingenuity System Inc, CA, USA) was used to interpret the data in the context of biological processes, pathways, and networks.

\section{Validation of microarray data}

\section{Retro-transcription polymerase chain reaction}

Retro-transcription reaction of RNA samples selected on the basis of their RIN values was carried out with the High-Capacity cDNA Archive kit (Applied Biosystems, Foster City, CA, USA) following the guidelines provided by the manufacturer and using Gene Amp 9700 PCR System thermocycler (Applied Biosystems). One RNA was processed in parallel in the absence of reverse transcriptase to rule out DNA contamination.

\section{Quantitative real-time polymerase chain reaction (RT-qPCR)}

RT-qPCR assays were conducted in duplicate on cDNA samples obtained from the retrotranscription reaction diluted 1:10 in 384-well optical plates (Kisker Biotech, Steinfurt, GE) utilizing the ABI Prism 7900 HT Sequence Detection System (Applied Biosystems). TaqMan probes (Thermo Fisher Scientific) used in the study are listed in Supplementary Table III. Selection of house-keeping genes was made on the basis of their preservation levels in human post-mortem brain $[51,52] . \Delta \Delta C T$ values were obtained from the $\Delta C T$ of each sample minus the mean $\triangle \mathrm{CT}$ of the population of control samples (calibrator samples). The fold-change was determined using the equation $2^{-\Delta \Delta C T}$. Mean fold-change values in each group were analyzed with the ANOVA one-way test using the Statgraphics Statistical Analysis and Data Visualization Software version 5.1.

\section{Statistical analysis}

Results were analyzed statistically with SPSS 19.0 (SPSS Inc., USA) software and GraphPad PRISM (GraphPad Software, Inc.) software. Data were presented as mean \pm standard error of the mean (SEM). Pearson's correlation method was used to assess a possible linear association between two continuous variables in the studied samples. Data were compared with two-tailed unpaired student t-test or one-way analysis of variance (ANOVA) followed by post-hoc Tukey's multiple comparison test when necessary. Differences between groups were considered statistically significant at ${ }^{*} p<0.05,{ }^{* *} p<0.01$ and ${ }^{* * *} p<0.001$. Tendencies were considered at $\# p<0.1$.

This article is protected by copyright. All rights reserved. 


\section{Results}

\section{General pathology of the LC: tau phosphorylation and tau-kinases}

The number of neurons with hyper-phosphorylated tau deposition was first analyzed in three non-consecutive sections of the rostral part of the LC at the level of the lower segment of the cerebral aqueduct of Sylvius in every case stained with the antibody AT8 which recognizes tau phosphorylation sites Ser202/Thr205, and expressed as the number of positive cells in relation to the total number of neurons per section (about 5,360 LC neurons counted in total). The number of AT8-immunoreactive neurons increased with age and stage progression from about $1 \%$ at stage I of NFT pathology to about $15 \%$ at stage IV (Fig $1 \mathrm{~A}$ ). Abnormal tau deposition was positive with tau-100 and 3Rtau and 4Rtau antibodies and with phospho-specific anti-tau antibodies P-tauThr181, P-tauSer262, P-tauSer422, and doublephosphorylated at Ser396/Ser404 (antibody PHF1). Most of them were also stained with conformation-specific antibodies Alz50 with tau modifications at amino acids 5-15, but only a minority of neurons were labeled with the antibody tau-C3 that recognizes truncated tau at aspartic acid 421 (Fig. 1B). Double-labeling immunofluorescence and confocal microscopy disclosed that $100 \%$ of P-tauThr181-positive neurons were stained with AT8 antibodies and about $80 \%$ of P-tauThr181-positive neurons with Alz50 antibodies (total number of PtauThr181-positive neurons counted: 236). Double-labeling immunofluorescence revealed that only about $5 \%$ of P-tauThr181-positive neurons were stained with tau-C3 antibody (total number of P-tauThr181-positive neurons counted: 128). Double-labeling immunofluorescence identified that only about $5 \%$ of AT8-positive neurons were stained with anti-ubiquitin antibodies in the LC at stages III and IV (total number of AT8-positive neurons counted: 214) (Fig. 1C). Immunoreactivity to tau-C3 and ubiquitin in neurons was restricted to those neurons bearing hyper-phosphorylated tau (100\% co-localization).

Double-labeling immunofluorescence and confocal microscopy showed total co-localization (100\%) of P-tauThr181 and MAPK/ERK-P (Thr202/Tyr204), and 100\% co-localization of AT8 and SAPK-JNK-P (Thr183/Tyr185), but $80 \%$ co-localization of AT8 and p38-P (Thr180/Tyr182), about $65 \%$ of AT8 and GSK-3ß-P (Ser9), and about $42 \%$ P-tauThr181 and GSK-P (Y279/Y216) in LC from stage I to stage IV (Fig. 2). Immunoreactivity to the several kinases was restricted to neurons with hyper-phosphorylated tau.

\section{Energy metabolism, and oxidative stress damage and responses}

Antibodies against voltage-dependent anion channel (VDAC) immunostaining were used as a marker of mitochondrial membranes. Double-labeling immunofluorescence and confocal microscopy showed that a minority of LC neurons bearing hyper-phosphorylated tau had decreased VDAC immunoreactivity (Fig. 3Aa-C). Double-labeling immunofluorescence with tau-C3 antibody and anti-VDAC disclosed decreased VDAC immunoreactivity only in the subpopulation of neurons stained with tau-C3 antibody (Fig. 3A, d-f).

This article is protected by copyright. All rights reserved. 
A decrease in superoxide dismutase 1 (SOD1) immunoreactivity was found in LC neurons with hyper-phosphorylated tau deposition when compared with neurons without tau in the same tissue section (Fig. 3B, a-c). This was accompanied by increased expression of neuroketal (NKT) restricted to LC neurons containing hyper-phosphorylated tau as revealed by double-labeling immunofluorescence and confocal microscopy (Fig. 3B, d-f). Quantitative studies at stages III and IV identified increased NKT immunoreactivity and decreased SOD1 immunoreactivity in practically the totality of LC neurons stained with anti-P-tauThr181 antibodies (total P-tauThr181-immunoractive neurons counted: 196).

Finally, double-labeling immunofluorescence with antibodies against specific antihemoglobin and AT8 showed reduced hemoglobin $\alpha$ and hemoglobin $\beta / Y$ immunoreactivity in all LC neurons containing hyper-phosphorylated tau in contrast with preservation of immunoreactivity in neighboring LC neurons lacking abnormal hyper-phosphorylated tau deposits (total AT8-immunoreactive neurons assessed: 232) (Fig. 3C, a-f). Importantly, erythropoietin receptor (EPOR) immunoreactivity was preserved in LC neurons with hyperphosphorylated tau deposition (Fig. 3C, g-i).

\section{Tyrosine-hydoxylase (TH) and synapses}

No modifications in TH immunoreactivity were observed in LC neurons bearing phospho-tau at stages I-IV of NFT pathology (Fig. 4A).

Reduced synaptophysin-immunoreactive perineuronal dots representing synaptic contacts with the neuronal cytoplasm were observed in LC neurons stained with tau-C3 antibodies (Fig. 4B). Quantitative studies (total neurons counted without NFTs: 126; total neurons with NFTs counted: 28) showed a decrease of between $40 \%$ and $60 \%$ of synaptophysinimmunoreactive dots on the cell surface of tau-C3-immunoreactive LC neurons when compared with LC neurons without tau-C3 in the same tissue section.

\section{Glial responses}

The number of astrocytes was not increased in LC at stages I-IV (data not shown). In contrast, a moderate increase in the number of microglial cells, as revealed with Iba-1 antibody, was found at stages III and IV of NFT pathology. Some microglial cells adopted a reactive morphology with short, thick varicose branches (Fig. 5A).

Using the same cases employed in whole transcriptome arrays, RT-qPCR showed significantly increased gene expression of AIF1 (which encodes Iba-1), CD68, PTGS2 (which encodes COX2), IL1,$I L 6$, and TNF- $\alpha$ in LC at stages III and IV of NFT pathology. In contrast, GFAP and IL10 mRNA expression levels were not modified in LC at the same stages (Fig. 5B).

This article is protected by copyright. All rights reserved. 


\section{$\alpha_{2 A}-A R$ and TH expression levels in hippocampus and amygdala at stages I-IV of NFT pathology}

First, the specificity of the anti- $\alpha_{2 A}-A R$ antibody was validated with immunoblot detection of the human $\alpha_{2 A}-A R$ transiently expressed in HEK-293T cells. The anti- $\alpha_{2 A}-A R$ detected several broad bands of $\sim 46,50,65 \mathrm{kDa}$ (Supplementary Figure 1, lane: $\alpha_{2 A}-A R$ ) which might correspond to non-glycosylated and glycosylated forms of the receptor, respectively [53]. As expected, the anti- $\alpha_{2 A}-A R$ did not detect any protein bands in cells transiently transfected with the empty vector (Supplementary Figure 1, lane: mock), thus indicating that the antibody was specific.

$\alpha_{2 A}-A R$ expression was significantly increased in the hippocampal membrane fraction at stage I, but it was significantly decreased at stage IV (Fig. 6A). Interestingly, TH expression declined with age/disease progression, with significantly lower levels at stages III and IV in the same samples (Fig. 6A). The expression of $\alpha_{2 A}-A R$ in the amygdala was also significantly increased at stage $\mathrm{I}$, whereas $\mathrm{TH}$ expression was significantly reduced at stages I-IV (Fig. 6B).

\section{Microarray analysis}

Pearson's correlation method showed no association among post-mortem delay, RIN values, and gender variables. The only association was age with NFT stages. After data normalization and filter application, no outliers were detected, and the cofactors were not relevant to the analysis and therefore all samples were included. A total of 6,870 gene set sequences were detected across all samples. Major differences in gene profile were identified in LC between stage I and stage IV of NFT pathology, as graphically illustrated in the heat map representation of significantly regulated transcripts at a probability of $<0.05$ (Fig. 7).

A complete list of de-regulated genes is found in Supplementary Table IV.

\section{Enrichment analysis against GO database and ingenuity pathway analysis (IPA)}

Statistical analysis revealed the most significant enrichment analysis against go ontology database $(p<0.05)$ was between stages I and IV of NFT pathology. Up-regulated genes coded for proteins were linked to protein folding, heat shock protein binding, and ATP metabolism. Down-regulated genes were linked to DNA binding and members of the small nucleolar RNAs family (SNOR).

Ingenuity pathway analysis revealed up-regulated pathways corresponding to 'neurological disease', 'hereditary disorder', and 'psychological disorders'. The analysis of molecular and cellular functions identified 'post-translational modification mechanisms', 'protein folding system', and 'cellular compromise components'. Detailed analysis is shown in Supplementary Data 4 and Supplementary Figure 2.

This article is protected by copyright. All rights reserved. 


\section{Validation of microarray data by qRT-PCR}

We selected five genes for validation from the four main altered functional pathways including: 1. protein folding mechanisms $H S P A 1 B$ and DNAJB1; 2. ATP metabolism ASPA6; 3. DNA/RNA binding proteins: ID1; and 4. Non-coding small nucleolar RNAs SCARNA2. Stages I, II, II and IV were included in the study.

RT-qPCR in LC samples confirmed significant up-regulation of HSPA1B and DNAJB1 at stage IV when compared with stage I; DNAJB1 was also significantly up-regulated at stage IV when compared with stage II.

HSPA6 was significantly up-regulated at stage IV when compared with stage I.

In contrast, ID4 was down-regulated at stage III when compared with stage I. A nonsignificant trend of reduction was also observed for ID4 at AD stage IV when compared with stage I.

Finally, SCARNA2 was down-regulated in LC at stages II, III, and IV when compared with stage I (Fig. 8).

\section{Discussion}

Cases in the present series were selected on the basis of the presence of NFTs in the LC in the context of early Braak staging of NFT pathology together with the absence of clinical symptoms related to cognitive impairment and major depression. All these cases can be categorized as preclinical $A D$ stages according to the $A B C$ classification proposed by the NIA/AA [54, 55]. However, it can be argued that some cases might not represent AD but rather primary age-related tauopathy (PART) [56,57], because most had no $\beta$-amyloid plaques in the brain (particularly those at NFT stages I and II, and some at stage III), and lesions were restricted to tau pathology [58]. This is difficult to discuss at present, as PART (formerly dementia with only tangles when advanced) has also been considered part of the $A D$ spectrum [59]. For this reason, herein we have avoided the term 'AD' and preferred to use the descriptive term of 'NFT pathology categorized as Braak stages'.

Seminal quantitative studies using unbiased methods have shown that neuron loss in the LC occurs at advanced stages of $A D[60,61]$. This has recently been determined in a more comprehensive study, using the unbiased stereological method of optical fractionators, showing that cell loss in the LC was insignificantly small at preclinical stages of AD [62]. Neuron loss occurs in prodromal $A D$ in cases with mild cognitive impairment, and neuron numbers markedly decrease in the LC along with progression of dementia [62]. The present study has taken advantage of these observations to focus on Braak stages of NFT pathology which do not significantly compromise the total number of neurons in the LC.

Expression of activated kinases involved in tau phosphorylation co-localizing with hyperphosphorylated tau deposits in the LC has the same characteristics as those reported in 
cerebral cortex in AD [63-66]. As described in other regions, phosphorylation of tau precedes altered tau conformation; tau truncation occurs only after complex tau phosphorylation, and tau truncation in neurons at aspartic acid 421 is needed to fully develop the cascade of NFT formation, including recruitment of full-length tau [67-73]. Strong association has been found between tau truncation at aspartic acid 421 and ubiquitin deposition in neurons in AD [74], and tau truncation has been proposed as an inducer of cell death via caspase activation [75].

Decreased VDAC immunoreactivity, suggesting a decrease in the number of mitochondria, was identified only in neurons containing truncated tau as revealed with the antibody tau-C3. Hyper-phosphorylated tau and particularly truncated tau produce mitochondrial damage [7679], thus accounting for decreased numbers of mitochondria in LC neurons bearing tau-C3. Hyper-phosphorylated tau deposition in LC neurons is accompanied by increased neuroketal adducts, indicating oxidative stress damage [80], and reduced SOD1 immunoreactivity, suggesting reduced oxidative stress responses in the same neurons and arguing in favor of increased oxidative damage in the LC at early stage NFT pathology [81-83]. Haemoglobin $\alpha$ and haemoglobin $\beta / \gamma$ immunoreactivity is also reduced in LC neurons with hyperphosphorylated tau deposition, as previously reported in neurons of the cerebral cortex in $A D$ [84]. It has been suggested that brain haemoglobin subunits may participate in redox homeostasis and mitochondrial activity [85, 86]. a-haemoglobin modulates antioxidant defenses and facilitates tyrosine hydroxylase synthesis and activity in peripheral catecholaminergic cells [87].

Microglia in the LC at middle stages of NFT pathology appear ramified with short branches, buds, and varicosities described as senescent microglia [88], a feature also observed in association with tau pathology in other brain regions [89]. These morphological changes are accompanied by increased mRNA expression of AIF1 (which encodes lba-1), PTGS2 (which encodes COX2), IL1 $\beta, I L 6$ and $T N F-\alpha$.

The timing of these alterations is similar to that seen in P301S transgenic mice used as a model of frontotemporal lobar dementia linked to mutations in MAPT (FTLD-tau) [90] and differs from biochemical responses of neurons and glial cells in mouse models of $\beta$-amyloid deposition [91].

Focal loss of synaptic contacts is found only in neurons bearing truncated tau. This alteration is seldom accompanied by focal synaptophysin immunoreactivity clustering, suggesting altered localization of synaptic molecules in this subpopulation of neurons. Reduced synaptic contacts have also been reported in tau-containing neurons in the hippocampus in AD [92], reinforcing the notion that reduced connectivity of neurons with NFTs may be due, in part, to progressive loss of synaptic inputs, leading to progressive neuronal isolation.

This article is protected by copyright. All rights reserved. 
Decreased TH immunoreactivity and increased neurons with NFTs in the LC occur in AD at advanced stages of the disease [14, 93]. The present findings show preserved $\mathrm{TH}$ immunoreactivity in LC neurons at asymptomatic Braak stages I-IV. Reduced cortical noradrenergic innervation and expression of adrenergic receptors have been reported in symptomatic AD [14, 94-96]. Reduced noradrenergic innervation is accompanied by sprouting noradrenergic afferents in the hippocampus [97], and compensatory changes in the LC and hippocampus in advanced stages of AD [98, 99]. Interestingly, dopamine betahydroxylase activity in plasma is decreased at early stages of $A D$, suggesting a compensatory mechanism for the loss of noradrenergic neurons [100].

The present findings show increased expression levels of $\alpha_{2 A}-A R s$ in the hippocampus and amygdala at first stages of NFT pathology occurring in parallel with local decrease of TH protein levels. The present observations show that compensatory changes in noradrenergic target nuclei might occur at very early Braak stages of NFT pathology.

The differentially expressed genes (DEG) obtained after the microarray raw data processing did not reach the high fold change levels commonly established for transcript selection. For this reason we selected those transcripts that showed the higher fold change, establishing in consequence as a treshold those values that showed an absolute fold change equal to or greater than 1.2 combined with unadjusted $p$-value $\leq 0.05$.

Whole transcriptome arrays have identified deregulated clusters including i) genes encoding proteins linked with protein folding, chaperone binding and heat shock protein bindingwhich were up-regulated at stage IV when compared with stage I; ii) genes associated with ATP metabolism, including genes associated with ATPase activator activity and ATPase regulator activity which were up-regulated at stage IV when compared with stage I; iii) genes coding for DNA-binding proteins which were down-regulated at stage IV when compared with stage I; and iv) members of the small nucleolar RNAs family (SNOR) down-regulated at stage IV when compared with stage I.

Representative elements of these four clusters were validated with RT-qPCR including heat shock protein members HSPA1A/Bis, HSPA6 (Hsp70, member 6), and DNAJB1 (HSP4O) [101-14]. Altered expression of these genes is not unexpected as they are likely linked to the abnormal tau protein and folding in NFTs. ID4 (Inhibitor of DNA binding 4) encodes a member of the inhibitor of DNA binding protein family which acts as helix-loop-helix transcription factors whose activity depends on the protein binding partner [105]. Small nucleolar RNAs (snoRNAs), including SCARNA2 (small Cajal body-specific RNA 2), are non-coding RNAs which regulate post-transcriptional processing of other non-coding RNAs, among other functions such as microRNA-dependent gene silencing and alternative splicing [106-108]. The involvement of DNA binding proteins and the snoRNA family in the pathology

This article is protected by copyright. All rights reserved. 
of $L C$ in $A D$ is relevant, as nuclear and nucleolar RNAs and proteins are emerging as key participants in neurodegeneration [109-111], and altered protein synthesis from the nucleolus to the ribosome has recently been reported in AD [112].

\section{Conclusions}

The present study shows that intraneuronal deposition of hyper-phosphorylated tau and misfolded tau, and incorporation of truncated tau in the LC at asymptomatic early and middle stages of NFT pathology are accompanied by altered mitochondria, reduced intraneuronal haemoglobin $\alpha$ and $\beta$, increased oxidative stress, and reduced stress responses. This concurs with microglia proliferation and increased expression of AIF1, CD68, PTGS2, IL1 $\beta$, IL6, and TNF- $\alpha$. Whole transcription analysis has shown novel altered metabolic pathways in the LC at early stages of NFT pathology including up-regulation of genes associated with protein folding and chaperone binding, and genes associated with ATP metabolism, and down-regulation of genes coding for DNA-binding proteins and members of the small nucleolar RNAs family. Tyrosine hydroxylase $(\mathrm{TH})$ immunoreactivity is preserved in neurons of LC but TH protein levels are decreased in the amygdala and hippocampus. Parallel increased expression levels of $\alpha_{2 A}$-ARs in the hippocampus and amygdala suggest compensatory activation in the face of decreased adrenergic input. Although subtle changes in mood and wake-sleep cycle disturbances, and discrete impairment of attention and learning capacity, cannot be excluded in this series, present observations unveil novel alterations in the LC and projections in asymptomatic individuals at early and middle stages of NFT pathology.

\section{References}

1. Delacourte A. The natural and molecular history of Alzheimer's disease. J Alzheimers Dis 2006; 9: 187-194

2. Duyckaerts C, Dickson DW. Neuropathology of Alzheimer's disease and its variants. In: Neurodegeneration: The molecular pathology of dementia and movement disorders. Eds DW Dickson, RO Weller. Basel: ISN Neuropath Press 2011: 47-65

3. Lowe J, Kalaria R. Dementia. In: Greenfield's Neuropathology, ninth edition. Eds S Love, H Budka, JW Ironside A Perry A. Boca Raton, London, New York: CRC Press 2015: 858973

This article is protected by copyright. All rights reserved. 
4. Braak H, Braak E. Neuropathological staging of Alzheimer-related changes. Acta Neuropathol 1991; 82: 239-259

5. Thal DR, Rüb $U$, Orantes $M$, Braak $H$. Phases of $A$ beta-deposition in the human brain and its relevance for the development of AD. Neurology 2002; 58:1791-1800

6. Braak $\mathrm{H}$, Del Tredici $\mathrm{K}$. The preclinical phase of the pathological process underlying sporadic Alzheimer's disease. Brain 2015;138: 2814-2833

7. Alafuzoff I, Arzberger T, Al-Sarraj S, Bodi I, Bogdanovic N, Braak H, Bugiani O, Del Tredici K, Ferrer I, Gelpi E, Giaccone G, Graeber, Ince P, Kamphorst W, King A, Korkolopoulou P, Kovács GG, Larionov S, Meyronet D, Monoranu C, Parchi P, Patsouris E, Roggendorf W, Seilhean D, Tagliavini F, Stadelmann C, Streichenberger N, Thal DR, Wharton SB, Kretzschmar $\mathrm{H}$. Staging of neurofibrillary pathology in Alzheimer's disease: a study of the BrainNet Europe Consortium. Brain Pathol 2008; 18: 484-496

8. Knopman DS, Parisi JE, Salviati A, Floriach-Robert M, Boeve BF, Ivnik RJ, Smith GE, Dickson DW, Johnson KA, Petersen LE, McDonald WC, Braak H, Petersen RC. Neuropathology of cognitively normal elderly. J Neuropathol Exp Neurol 2003; 62: 10871095

9. Price JL, McKeel DW, Buckles VD, Roe CM, Xiong C, Grundman M, Hansen LA, Petersen RC, Parisi JE, Dickson DW, Smith CD, Davis DG, Schmitt FA, Markesbery WR, Kaye J, Kurlan R, Hulette C, Kurland BF, Higdon R, Kukull W, Morris JC. Neuropathology of non-demented aging: presumptive evidence for preclinical Alzheimer disease. Neurobiol Aging 2009; 30: 1026-1036

10. Nelson PT, Alafuzoff I, Bigio EH, Bouras C, Braak H, Cairns NJ, Castellani RJ, Crain BJ, Davies P, Del Tredici K, Duyckaerts C, Frosch MP, Haroutunian V, Hof PR, Hulette CM, Hyman BT, Iwatsubo T, Jellinger KA, Jicha GA, Kövari E, Kukull WA, Leverenz JB, Love S, Mackenzie IR, Mann DM, Masliah E, McKee AC, Montine TJ, Morris JC, Schneider JA, Sonnen JA, Thal DR, Trojanowski JQ, Troncoso JC, Wisniewski T, Woltjer RL, Beach TG. Correlation of Alzheimer disease neuropathologic changes with cognitive status: a review of the literature. J Neuropathol Exp Neurol 2012; 71: 362-381

This article is protected by copyright. All rights reserved. 
11. Braak H, Thal DR, Ghebremedhin E, Del Tredici K. Stages of the pathologic process in Alzheimer disease: age categories from 1 to 100 years. J Neuropathol Exp Neurol 2011; 70: 960-969

12. Ferrer I. Defining Alzheimer as a common age-related neurodegenerative process not inevitably leading to dementia. Prog Neurobiol 2012; 97: 38-51

13. Usher M, Cohen JD, Servan-Schreiber D, Rajkowski J, Aston-Jones G. The role of locus coeruleus in the regulation of cognitive performance. Science 1999; 283: 549-553

14. Šimić G, Babić Leko M, Wray $S$, Harrington $C R$, Delalle I, Jovanov-Milošević $N$, Bažadona $\quad D$, Buée $L$, de Silva $R$, Di Giovanni G, Wischik CM, Hof PR. Monoaminergic neuropathology in Alzheimer's disease. Prog Neurobiol 2016; Apr 12. pii: S0301-0082(15)30089-7. doi: 10.1016/j.pneurobio.2016.04.001 [Epub ahead of print]

15. Westlund KN, Bowker RM, Ziegler MG, Coulter JD. Descending noradrenergic projections and their spinal terminations. Prog Brain Res 1982; 57: 219-238

16. Foote SL, Morrison JH. Development of the noradrenergic, serotonergic, and dopaminergic innervation of neocortex. Curr Top Dev Biol 1987; 21: 391-423

17. Petrov T, Krukoff TL, Jhamandas JH. Branching projections of catecholaminergic brainstem neurons to the paraventricular hypothalamic nucleus and the central nucleus of the amygdala in the rat. Brain Res 1993; 609: 81-92

18. Raghanti MA, Spocter MA, Stimpson CD, Erwin JM, Bonar CJ, Allman JM, Hof PR, Sherwood CC. Species-specific distributions of tyrosine hydroxylase-immunoreactive neurons in the prefrontal cortex of anthropoid primates. Neuroscience 2009; 158: 1551-1559

19. Samuels ER, Szabadi E. Functional neuroanatomy of the noradrenergic locus coeruleus: its roles in the regulation of arousal and autonomic function part II: physiological and pharmacological manipulations and pathological alterations of locus coeruleus activity in humans. Curr Neuropharmacol 2008; 6: 254-285

20. Heimer L. The human brain and spinal cord, $2^{\text {nd }}$ edition Springer-Verlag, New York, Berlin, 1995

This article is protected by copyright. All rights reserved. 
21. Sara SJ. The locus coeruleus and noradrenergic modulation of cognition. Nat Rev Neurosci 2009; 10: 211-223

22. Mason ST. Noradrenaline in the brain: progress in theories of behavioral function. Prog Neurobiol 1981; 16: 263-303

23. Harley CW. A role for norepinephrine in arousal, emotion and learning? limbic modulation by norepinephrine and the Kety hypothesis. Prog Neuropsychopharmacol Biol Psychiatry 1987; 11: 419-458

24. Kayama Y, Koyama Y. Control of sleep and wakefulness by brainstem monoaminergic and cholinergic neurons. Acta Neurochir 2003; 87: 3-6

25. Aston-Jones G, Cohen JD. An integrative theory of locus coeruleus-norepinephrine function: adaptive gain and optimal performance. Annu Rev Neurosci 2005; 28: 403-450

26. Heneka MT, Nadrigny F, Regen T, Martinez-Hernandez A, Dumitrescu-Ozimek L, Terwel D, Jardanhazi-Kurutz D, Walter J, Kirchhoff F, Hanisch UK, Kummer MP. Locus ceruleus controls Alzheimer's disease pathology by modulating microglial functions through norepinephrine. Proc Natl Acad Sci USA 2010; 107: 6058-6063

27. Bekar LK, Wei HS, NedergaardM. The locus coeruleus-norepinephrine network optimizes coupling of cerebral blood volume with oxygen demand. J Cereb Blood Flow Metab 2012; 32: 2135-2145

28. Szabadi E. Functional neuroanatomy of the central noradrenergic system. $J$ Psychopharmacol 2013; 27: 659-693

29. Ruffolo RR Jr, Hieble JP. Alpha-adrenoceptors. Pharmacol Ther 1994; 61: 1-64

30. Singewald N, Philippu A. Release of neurotransmitters in the locus coeruleus. Prog Neurobiol 1998; 56: 237-267

31 Mravec B, Lejavova K, Cubinkova V. Locus (coeruleus) minoris resistentiae in pathogenesis of Alzheimer's disease. Curr Alzheimer Res 2014; 11: 992-1001

This article is protected by copyright. All rights reserved. 
32. Tomlinson BE, Irving D, Blessed G. Cell loss in the locus coeruleus in senile dementia of Alzheimer type. J Neurol Sci 1981; 49: 419-428

33. Bondareff $W$, Mountjoy $C Q$, Roth $M$. Loss of neurons of origin of the adrenergic projection to cerebral cortex (nucleus locus ceruleus) in senile dementia. Neurology 1982; 32: $164-168$

34. Iversen LL, Rossor MN, Reynolds GP, Hills R, Roth M, Mountjoy CQ, Foote SL, Morrison $\mathrm{JH}$, Bloom FE. Loss of pigmented dopamine-beta-hydroxylase positive cells from locus coeruleus in senile dementia of Alzheimer's type. Neurosci Lett 1983; 39: 95-100

35. German DC, White CL III, Sparkman DR. Alzheimer's disease: neurofibrillary tangles in nuclei that project to the cerebral cortex. Neuroscience 1987; 21: 305-312

36. Zweig RM, Ross CA, Hedreen JC, Steele C, Cardillo JE, Whitehouse PJ, Folstein MF, Price DL. The neuropathology of aminergic nuclei in Alzheimer's disease. Ann Neurol 1988; 24: $233-242$

37. Chan-Palay V, Asan E. Alterations in catecholamine neurons of the locus coeruleus in senile dementia of the Alzheimer type and in Parkinson's disease with and without dementia and depression. J Comp Neurol 1989; 287: 373-392

38. Rüb U, Del Tredici K, Schultz C, Thal DR, Braak E, Braak H. The autonomic higher order processing nuclei of the lower brain stem are among the early targets of the Alzheimer's disease-related cytoskeletal pathology. Acta Neuropathol 2001; 101: 555-564

39. Šimić G, Mladinov M, Jovanov-Milosevic N, Kostovic I, Hof PR. Does Alzheimer's disease begin in the brainstem? Neuropathol Appl Neurobiol 2009; 35: 532-554

40. Grinberg LT, Rüb U, Ferretti RE, Nitrini R, Farfel JM, Polichiso L, Gierga K, Jacob-Filho W, Heinsen H; Brazilian Brain Bank Study Group. The dorsal raphe nucleus shows phosphotau neurofibrillary changes before the transentorhinal region in Alzheimer's disease. A precocious onset? Neuropathol Appl Neurobiol 2009; 35: 406-416

41. Attems J, Thal DR, Jellinger KA. The relationship between subcortical tau pathology and Alzheimer's disease. Biochem Soc Trans 2012; 40: 711-715 
42. Rodríguez JJ, Noristani HN, Verkhratsky A. The serotonergic system in ageing and Alzheimer's disease. Prog Neurobiol 2012; 99:15-41

43. Braak H, Alafuzoff I, Arzberger T, Kretzschmar H, Del Tredici K. Staging of Alzheimer disease-associated neurofibrillary pathology using paraffin sections and immunocytochemistry. Acta Neuropathol 2006; 112: 389-404

44. Mirra SS, Heyman A, McKeel D, Sumi SM, Crain BJ, Brownlee LM, Vogel FS, Hughes JP, van Belle G, Berg L. The Consortium to Establish a Registry for Alzheimer's Disease (CERAD). Part II. Standardization of the neuropathologic assessment of Alzheimer's disease. Neurology 1991; 41: 479-486

45. German DC, Walker BS, Manaye K, Smith WK, Woodward DJ, North AJ. The human locus coeruleus: computer reconstruction of cellular distribution. J Neurosci 1988; 8: 17781788

46. West MJ, Slomianka L, Gundersen HJ. Unbiased stereological estimation of the total number of neurons in the subdivisions of the rat hippocampus using the optical fractionator. Anat Rec 1991; 231: 482-497

47. Burgueño J, Enrich C, Canela El, Mallol J, Lluis C, Franco R, Ciruela F. Metabotropic glutamate type 1alpha receptor localizes in low-density caveolin-rich plasma membrane fractions. J Neurochem 2003; 86: 785-791

48. Van Gelder RN, von Zastrow ME, Yool A, Dement WC, Barchas JD, Eberwine JH. Amplified RNA synthesized from limited quantities of heterogeneous cDNA. Proc Natl Acad Sci USA 1990; 87: 1663-1667

49. Gentleman RC, Carey VJ, Bates DM, Bolstad B, Dettling M, Dudoit S, Ellis B, Gautier L, Ge Y, Gentry J, Hornik K, Hothorn T, Huber W, lacus S, Irizarry R, Leisch F, Li C, Maechler M, Rossini AJ, Sawitzki G, Smith C, Smyth G, Tierney L, Yang JY, Zhang J. Bioconductor: open software development for computational biology and bioinformatics. Genome Biol 2004; 5: R80 
50. Smyth GK. Linear models and empirical bayes methods for assessing differential expression in microarray experiments. Stat Appl Genet Mol Biol 2004; 3: Article 3

51. Barrachina M, Castaño E, Ferrer I. TaqMan PCR assay in the control of RNA normalization in human post-mortem brain tissue. Neurochem Int 2006; 49: 276-284

52. Durrenberger PF, Fernando FS, Magliozzi R, Kashefi SN, Bonnert TP, Ferrer I, Seilhean D, Nait-Oumesmar B, Schmitt A, Gebicke-Haerter PJ, Falkai P, Grünblatt E, Palkovits M, Parchi P, Capellari S, Arzberger T, Kretzschmar H, Roncaroli F, Dexter DT, Reynolds R. Selection of novel reference genes for use in the human central nervous system: a BrainNet Europe Study. Acta Neuropathol 2012; 124: 893-903

53. Regan JW, Nakata H, DeMarinis RM, Caron MG, Lefkowitz RJ. Purification and characterization of the human platelet alpha 2-adrenergic receptor. J Biol Chem 1986; 261 : 3894-3900

54. Hyman BT, Phelps CH, Beach TG, Bigio EH, Cairns NJ, Carrillo MC, Dickson DW, Duyckaerts C, Frosch MP, Masliah E, Mirra SS, Nelson PT, Schneider JA, Thal DR, Thies B, Trojanowski JQ, Vinters HV, Montine TJ. National Institute on Aging-Alzheimer's Association guidelines for the neuropathologic assessment of Alzheimer's disease. Alzheimers Dement 2012; 8: 1-13

55. Montine TJ, Phelps CH, Beach TG, Bigio EH, Cairns NJ, Dickson DW, Duyckaerts C, Frosch MP, Masliah E, Mirra SS, Nelson PT, Schneider JA, Thal DR, Trojanowski JQ, Vinters HV, Hyman BT; National Institute on Aging; Alzheimer's Association. National Institute on Aging-Alzheimer's Association guidelines for the neuropathologic assessment of Alzheimer's disease: a practical approach. Acta Neuropathol 2012; 123: 1-11

56. Crary JF, Trojanowski JQ, Schneider JA, Abisambra JF, Abner EL, Alafuzoff I, Arnold SE, Attems J,Beach TG, Bigio EH, Cairns NJ, Dickson DW, Gearing M, Grinberg LT,Hof PR, Hyman BT, Jellinger K, Jicha GA, Kovacs GG, Knopman DS, Kofler J, Kukull WA, Mackenzie IR, Masliah E, McKee A, Montine TJ, Murray ME, Neltner JH, Santa-Maria I, Seeley WW, Serrano-Pozo A, Shelanski ML, Stein T, Takao M, Thal DR, Toledo JB, Troncoso JC, Vonsattel JP, White CL 3rd, Wisniewski T, Woltjer RL, Yamada M, Nelson PT. Primary age-related tauopathy (PART): a common pathology associated with human aging. Acta Neuropathol 2014; 128: 755-766 
57. Jellinger KA, Alafuzoff I, Attems J, Beach TG, Cairns NJ, Crary JF, Dickson DW, Hof PR, Hyman BT, Jack CR Jr, Jicha GA, Knopman DS, Kovacs GG, Mackenzie IR, Masliah E, Montine TJ, Nelson PT, Schmitt F, Schneider JA, Serrano-Pozo A, Thal DR, Toledo JB, Trojanowski JQ, Troncoso JC, Vonsattel JP, Wisniewski T. PART, a distinct tauopathy, different from classical sporadic Alzheimer disease. Acta Neuropathol 2015; 129: 757-762

58. Giaccone $\mathrm{G}$. The existence of primary age-related tauopathy suggests that not all the cases with early Braak stages of neurofibrillary pathology are Alzheimer's disease. $J$ Alzheimers Dis 2015; 48: 919-921

59. Duyckaerts C, Braak H, Brion JP, Buée L, Del Tredici K, Goedert M, Halliday G, Neumann M, Spillantini MG, Tolnay M, Uchihara T. PART is part of Alzheimer disease. Acta Neuropathol 2015; 129: 749-756

60. Ohm TG, Busch C, Bohl J. Unbiased estimation of neuronal numbers in the human nucleus coeruleus during aging. Neurobiol Aging 1997; 18: 393-399

61. Busch C, Bohl J, Ohm TG. Spatial, temporal and numeric analysis of Alzheimer changes in the nucleus coeruleus. Neurobiol Aging 1997; 18: 401-446

62. Arendt T, Brückner MK, Morawski M, Jäger C, Gertz HJ. Early neurone loss in Alzheimer's disease: cortical or subcortical? Acta Neuropathol Commun 2015; 3: 10

63. Atzori C, Ghetti B, Piva R, Srinivasan AN, Zolo P, Delisle MB, Mirra SS, Migheli A. Activation of the JNK/p38 pathway occurs in diseases characterized by tau protein pathology and is related to tau phosphorylation but not to apoptosis. J Neuropathol Exp Neurol 2001; 60: $1190-1197$

64. Ferrer I, Blanco R, Carmona M, Puig B. Phosphorylated mitogen-activated protein kinase (MAPK/ERK-P), protein kinase of $38 \mathrm{kDa}$ (p38-P), stress-activated protein kinase (SAPK/JNK-P), and calcium/calmodulin-dependent kinase II (CaM kinase II) are differentially expressed in tau deposits in neurons and glial cells in tauopathies. J Neural Transm 2001; 108: $1397-1415$

65. Ferrer I, Blanco R, Carmona M, Ribera R, Goutan E, Puig B, Rey MJ, Cardozo A, Viñals F, Ribalta T. Phosphorylated map kinase (ERK1, ERK2) expression is associated with early tau deposition in neurones and glial cells, but not with increased nuclear DNA vulnerability

This article is protected by copyright. All rights reserved. 
and cell death, in Alzheimer disease, Pick's disease, progressive supranuclear palsy and corticobasal degeneration. Brain Pathol 2001; 11: 144-158

66. Ferrer I, Barrachina M, Puig B. Glycogen synthase kinase-3 is associated with neuronal and glial hyperphosphorylated tau deposits in Alzheimer's disease, Pick's disease, progressive supranuclear palsy and corticobasal degeneration. Acta Neuropathol 2002; 104: 583-591

67. García-Sierra F, Ghoshal N, Quinn B, Berry R, Binder LI. Conformational changes and truncation of tau protein during tangle evolution in Alzheimer's disease. J Alzheimer's Dis 2003; 5: 65-77

68. Luna-Muñoz J, García-Sierra F, Falcón V, Menéndez I, Chávez-Macías L, Mena R. Regional conformational change involving phosphorylation of tau protein at the Thr231 precedes the structural change detected by Alz-50 antibody in Alzheimer's disease. $J$ Alzheimers Dis 2005; 8: 29-41

69. Luna-Muñoz J, Chávez-Macías L, García-Sierra F, Mena R. Earliest stages of tau conformational changes are related to the appearance of a sequence of specific phosphodependent tau epitopes in Alzheimer's disease. J Alzheimers Dis 2007; 12: 365-375

70. Mondragón-Rodríguez S, Basurto-Islas G, Santa-María I, Mena R, Binder LI, Avila J, Smith MA, Perry G, García-Sierra F. Cleavage and conformational changes of tau protein follow phosphorylation during Alzheimer's disease. Int J Exp Path 2008; 89: 81-90

71. Mena R, Luna-Muñoz J. Stages of pathological tau-protein processing in Alzheimer's disease: from soluble aggregations to polymerization into insoluble tau-PHFs. In: Current hypothesis and research milestones in Alzheimer's disease. Eds. R Maccione, G Perry. Heidelberg: Springer. 2008: 79-91

72. Kovacech B, Novak M. Tau truncation is a productive posttranslational modification of neurofibrillary degeneration in Alzheimer's disease. Curr Alzheimer Res 2010; 7: 708-716

73. Ferrer I, López-González I, Carmona M, Arregui L, Dalfó E, Torrejón-Escribano B, Diehl R, Kovacs GG. Glial and neuronal tau pathology in tauopathies: characterization of diseasespecific phenotypes and tau pathology progression. J Neuropathol Exp Neurol 2014; 73: 8197

This article is protected by copyright. All rights reserved. 
74. García-Sierra F, Jarero-Basulto JJ, Kristofikova Z, Majer E, Binder LI, Ripova D. Ubiquitin is associated with early truncation of tau protein at aspartic acid (421) during the maturation of neurofibrillary tangles in Alzheimer's disease. Brain Pathol 2012; 22: 240-250

75. Zilkova M, Zilka N, Kovac A, Kovacech B, Skrabana R, Skrabanova M, Novak M. Hyperphosphorylated truncated protein tau induces caspase-3 independent apoptosis-like pathway in the Alzheimer's disease cellular model. $J$ Alzheimers Dis 2011; 23: 161-169

76. Kopeikina KJ, Carlson GA, Pitstick R, Ludvigson AE, Peters A, Luebke JI, Koffie RM, Frosch MP, Hyman BT, Spires-Jones TL. Tau accumulation causes mitochondrial distribution deficits in neurons in a mouse model of tauopathy and in human Alzheimer's disease brain. Am J Pathol 2011; 179: 2071-2282

77. Schmitt K, Grimm A, Kazmierczak A, Strosznajder JB, Götz J, Eckert A. Insights into mitochondrial dysfunction: aging, amyloid- $\beta$, and tau- $A$ deleterious trio. Antioxid Redox Signal 2012; 16: 1456-1466

78. Quintanilla RA, Dolan PJ, Jin YN, Johnson GV. Truncated tau and $A \beta$ cooperatively impair mitochondria in primary neurons. Neurobiol Aging 2012; 33: 619.e25-35

79. Ozcelik S, Sprenger F, Skachokova Z, Fraser G, Abramowski D, Clavaguera F, Probst A, Frank S, Müller M, Staufenbiel M, Goedert M, Tolnay M, Winkler DT. Co-expression of truncated and full-length tau induces severe neurotoxicity. Mol Psychiatry 2016; 21: 17901798

80. Domínguez $M$, de Oliveira E, Odena MA, Portero M, Pamplona R, Ferrer I. Redox proteomic profiling of neuroketal-adducted proteins in human brain: Regional vulnerability at middle age increases in the elderly. Free Radic Biol Med 2016; 95:1-15

81. Bonda DJ, Wang X, Perry G, Nunomura A, Tabaton M, Zhu X, Smith MA. Oxidative stress in Alzheimer disease: a possibility for prevention. Neuropharmacology 2010; 59: 290294.

82. von Bernhardi R, Eugenín J. Alzheimer's disease: redox dysregulation as a common denominator for diverse pathogenic mechanisms. Antioxid Redox Signal 2012; 16: 974-1031

This article is protected by copyright. All rights reserved. 
83. Wang X, Wang W, Li L, Perry G, Lee HG, Zhu X. Oxidative stress and mitochondrial dysfunction in Alzheimer's disease. Biochim Biophys Acta 2014; 1842: 1240-1247

84. Ferrer I, Gómez A, Carmona M, Huesa G, Porta S, Riera-Codina M, Biagioli M, Gustincich S, Aso E. Neuronal hemoglobin is reduced in Alzheimer's disease, argyrophilic grain disease, Parkinson's disease, and dementia with Lewy bodies. J Alzheimers Dis 2011; 23: $537-550$

85. Nishi $H$, Inagi $R$, Kato $H$, Tanemoto $M$, Kojima I, Son D, Fujita T, Nangaku $M$. Hemoglobin is expressed by mesangial cells and reduces oxidant stress. J Am Soc Nephrol 2008; 19: 1500-1508

86. Biagioli M, Pinto M, Cesselli D, Zaninello M, Lazarevic D, Roncaglia P, Simone R, Vlachouli C, Plessy C, Bertin N, Beltrami A, Kobayashi K, Gallo V, Santoro C, Ferrer I, Rivella S, Beltrami CA, Carninci P, Raviola E, Gustincich S. Unexpected expression of $\alpha$ and $\beta$-globin in mesencephalic dopaminergic neurons and glial cells. Proc Natl Acad Sci USA 2009; 106: 15454-15459.

87. Marcos-Almaraz MT, Rodríguez-Gómez J, López-Barneo J, Pascual A. a-haemoglobin regulates sympathoadrenal cell metabolism to maintain a catecholaminergic phenotype. Biochem J 2012; 441: 843-850

88. Streit WJ, Xue QS. Microglial senescence. CNS Neurol Disord Drug Targets 2013; 12: 763-767

89. Streit WJ, Braak H, Xue QS, Bechmann I. Dystrophic (senescent) rather than activated microglial cells are associated with tau pathology and likely precede neurodegeneration in Alzheimer's disease. Acta Neuropathol 2009; 118: 475-485

90. López-González I, Aso E, Carmona M, Armand-Ugon M, Blanco R, Naudí A, Cabré R, Portero-Otin M, Pamplona R, Ferrer I. Neuroinflammatory gene regulation, mitochondrial function, oxidative stress, and brain lipid modifications with disease progression in tau P301S transgenic mice as a model of frontotemporal lobar degeneration-tau. $J$ Neuropathol Exp Neurol 2015; 74: 975-999

91. López-González I, Schlüter A, Aso E, Garcia-Esparcia P, Ansoleaga B, LLorens F, Carmona M, Moreno J, Fuso A, Portero-Otin M, Pamplona R, Pujol A, Ferrer I. 
Neuroinflammatory signals in Alzheimer disease and APP/PS1 transgenic mice: correlations with plaques, tangles, and oligomeric species. J Neuropathol Exp Neurol 2015; 74: 319-344

92. Merino-Serrais $P$, Benavides-Piccione R, Blazquez-Llorca L, Kastanauskaite A, Rábano A, Avila J, DeFelipe J. The influence of phospho-T on dendritic spines of cortical pyramidal neurons in patients with Alzheimer's disease. Brain 2013; 136: 1913-1928

93. Grudzien A, Shaw P, Weintraub S, Bigio E, Mash DC, Mesulam MM. Locus coeruleus neurofibrillary degeneration in aging, mild cognitive impairment and early Alzheimer's disease. Neurobiol Aging 2007; 28: 327-335

94. Yates CM, Simpson J, Gord on A, Maloney AF, Allison Y, Ritchie IM, Urquhart A. Catecholamines and cholinergic enzymes in pre-senile and senile Alzheimer-type dementia and Down's syndrome. Brain Res 1983; 280:119-126

95. Kalaria RN, Andorn AC. Adrenergic receptors in aging and Alzheimer's disease: decreased alpha 2-receptors demonstrated by $[3 \mathrm{H}] \mathrm{p}$-aminoclonidine binding in prefrontal cortex. Neurobiol Aging 1991; 12: 131-136

96. Chalermpalanupap T, Kinkead B, Hu WT, Kummer MP, Hammerschmidt T, Heneka MT, Weinshenker D, Levey Al. Targeting norepinephrine in mild cognitive impairment and Alzheimer's disease. Alzheimer's Res Ther 2013; 5: 21

97. Booze RM, Mactutus CF, Gutman CR, Davis JN. Frequency analysis of catecholamine axonal morphology in human brain. II. Alzheimer's disease and hippocampal sympathetic ingrowth. J Neurol Sci 1993; 119: 110-118

98. Hoogendijk WJ, Feenstra MG, Botterblom MH, Gilhuis J, Sommer IE, Kamphorst W, Eikelenboom P, Swaab DF. Increased activity of surviving locus ceruleus neurons in Alzheimer's disease. Ann Neurol 1999; 45: 82-91

99. Szot P, White SS, Greenup JL, Leverenz JB, Peskind ER, Raskind MA. Compensatory changes in the noradrenergic nervous system in the locusceruleus and hippocampus of postmortem subjects with Alzheimer's disease and dementia with Lewy bodies. $J$ Neurosci 2006; 26: 467-478

This article is protected by copyright. All rights reserved. 
100. Mustapic M, Presecki P, Pivac N, Mimica N, Hof PR, Simic G, Folnegovic-Simic V, Muck-Seler D. Genotype-independent decrease in plasma dopamine beta-hydroxylase activity in Alzheimer's disease. Progr Neuropsychopharmacol Biol Psychiatry 2013; 44: 9499

101. Young JC. Mechanisms of the Hsp70 chaperone system. Biochem Cell Biol 2010; 88: 291-300

102. Kakkar V, Prins LC, Kampinga HH. DNAJ proteins and protein aggregation diseases. Curr Top Med Chem 2012; 12: 2479-2490

103. Priya S, Sharma SK, Goloubinoff P. Molecular chaperones as enzymes that catalytically unfold misfolded polypeptides. FEBS Lett 2013; 587: 1981-1987

104. Shiber A, Ravid T. Chaperoning proteins for destruction: diverse roles of Hsp70 chaperones and their co-chaperones in targeting misfolded proteins to the proteasome. Biomolecules 2014; 4: 704-724

105. Patel D, Morton DJ, Carey J, Havrda MC, Chaudhary J. Inhibitor of differentiation 4 (ID4): From development to cancer. Biochim Biophys Acta 2015; 1855: 92103

106. Stepanov GA, Filippova JA, Komissarov AB, Kuligina EV, Richter VA, Semenov DV. Regulatory role of small nucleolar RNAs in human diseases. Biomed Res Int 2015: 206849

107. Bhartiya D, Scaria V. Genomic variations in non-coding RNAs: Structure, function and regulation. Genomics 2016; 107: 59-68

108. Jorjani H, Kehr S, Jedlinski DJ, Gumienny R, Hertel J, Stadler PF, Zavolan M, Gruber AR. An updated human snoRNAome. Nucleic Acids Res May 2016; 44: 5068-5082

109. Baltanás FC, Casafont I, Lafarga V, Weruaga E, Alonso JR, Berciano MT, Lafarga M. Purkinje cell degeneration in pcd mice reveals large scale chromatin reorganization and gene silencing linked to defective DNA repair. J Biol Chem 2011; 286: 28287-2302

110. Baltanás FC, Valero J, Alonso JR, Berciano MT, Lafarga M. Nuclear signs of preneurodegeneration. Methods Mol Biol 2015; 1254: 43-54

This article is protected by copyright. All rights reserved. 
111. Mata-Garrido J, Casafont I, Tapia O, Berciano MT, Lafarga M. Neuronal accumulation of unrepaired DNA in a novel specific chromatin domain: structural, molecular and transcriptional characterization. Acta Neuropathol Commun 2016; 4: 41

112. Hernández-Ortega K, Garcia-Esparcia P, Gil L, Lucas JJ, Ferrer I. Altered machinery of protein synthesis in Alzheimer's: from the nucleolus to the ribosome. Brain Pathol 2016; 26: 593-605.

\section{Acknowledgements}

The research was given ethical approval. Microarrays were carried out at the High Technology Unit (UAT), Vall d'Hebron Research Institute (VHIR), Barcelona, Spain. We wish to thank Ferran Briansó, Unit of Statistics and Bioinformatics, VHIR, for the preliminary bioinformatics processing of data, and we thank T. Yohannan for editorial help.

\section{Contribution of the authors}

PA-B carried out the study of arrays and RT-qPCR validation; VFD, the molecular studies in the hippocamopus and amygdala; MC, immunohistochemistry and tissue preparation; LAE, quantitative studies on immunohistochemical sections; BT-E, confocal microscopy studies. EA contributed to statitiscal assessment and data processing; FC directed molecular studies of the noradrenergic system; IF designed the study, supervised the results, and wrote the first advanced version of the manuscript which was circulated among all the contributors for comments and suggestions. All of the authors contributed to the final version of the manuscript.

This article is protected by copyright. All rights reserved. 


\section{Figure legends}

Figure 1: A) Percentage of neurons containing hyper-phosphorylated tau deposition as revealed with AT8 antibody in LC at Braak stages I, II, II and IV of NFT pathology. Mean values of each group were compared with one-way analysis of variance (ANOVA) followed by post-hoc Tukey's multiple comparison test, and differences were considered statistically significant at $\$ p<0.05 ; \$ p<0.01 ; \$ \$ p<0.001$ compared with stage $1 ; \& p<0.05 ; \& \& p$ $<0.01 ; \& \& \& \mathrm{p}<0.001$ compared with stage II; and $\sim \mathrm{p}<0.05 ; \sim \mathrm{p}<0.01 ; \sim \sim \mathrm{p}<0.001$ compared with stage III. B) Immunostaining of tau-positive neurons in LC using different anti-tau antibodies: a: tau 100; b: 3Rtau; c: 4Rtau; d: P-tauThr181; e: P-tauSer262; f: AT8; g: PHF; h: Alz50; i: tau-C3; bar = $25 \mu \mathrm{m}$. C) Double-labeling immunofluorescence and confocal microscopy using combinations of anti-tau antibodies and anti-ubiquitin; a-c: Alz50 (green) and P-tauThr181 (red); d-f: tau-C3 (green) and P-tauThr181 (red); g-i: ubiquitin (green) and P-tauThr 181 (red) in LC. c, f, i: merge. Nuclei stained with DRAQ5 ${ }^{\mathrm{TM}}$ (blue); bar $=30 \mu \mathrm{m}$.

Figure 2: Expression and localization of tau kinases and hyper-phosphorylated tau in LC as revealed by double-labeling immunofluorescence and confocal microscopy. a-c: PtauThr181 (green) and MAPK-ERK-P (red); d-f: AT8 (green) and SAPK-JNK-P (red); g-i: AT8 (green) and p38-P (red); j-l: AT8 (green) and GSK-3ß-P (Ser9) (red); m-0: P-tauThr181 (green) and GSK-P (Y279/Y216) (red); c, f, i, I, o: merge. Nuclei stained with DRAQ5 ${ }^{\mathrm{TM}}$ (blue); bar $=50 \mu \mathrm{m}$.

Figure 3: Mitochondria, oxidative stress and responses, and hemoglobin in LC. A) Mitochondria; a-c: Decreased VDAC (green) immunoreactivity is seen in a minority of neurons containing P-tauThr181 (red); d-f: VDAC immunoreactivity is decreased in neurons containing tau-C3 (red) arrow; c, f: merge; bar $=50 \mu \mathrm{m}$. B) Oxidative stress and responses; a-c SOD1 immunoreactivity (red) is reduced in neurons with P-tauThr181 (arrow); d-f: PtauThr181 (green) and neuroketal (red) co-localize in neurons; bar $=50 \mu \mathrm{m}$. C) Hemoglobin and erythropoietin receptor; a-c: $\mathrm{Hb}$ alpha (red) is reduced in AT8-immunoractive (green) neurons; d-f: $\mathrm{Hb}$ beta (red) immunoreactivity is also decreased in AT8-positive neurons (green), whereas g-i: EPO receptor (red) is present in tau containing neurons; bar $=50 \mu \mathrm{m}$. $c, f, i:$ merge. Nuclei stained with DRAQ5 ${ }^{\mathrm{TM}}$ (blue)

This article is protected by copyright. All rights reserved. 
Figure 4: Tyrosine hydroxylase and synaptophysin in LC neurons. A) TH immunoreactivity (green) is expressed equally in neurons with phospho-tau immunoreactive (red) and negative neurons at Braak stage IV of NFT pathology; c: merge; bar $=50 \mu \mathrm{m}$. B) Reduced synaptophysin-immunoreactive dots (green) in neurons containing tau-C3-immunoreactive deposits (red); remaining dots are labeled with arrows; stage IV of NFT pathology; c: merge; bar $=20 \mu \mathrm{m}$. Nuclei stained with DRAQ5 ${ }^{\mathrm{TM}}$ (blue).

Figure 5: A) Immunohistochemistry to Iba1 in the LC at Braak stages I (a), III (B), and IV (c) of NFT pathology. Moderate increase in the number of Iba-1-immunoreactive cells is found along with disease progression; microglial cells with short, thick, and varicose branches also present. B) mRNA expression of AIF1 (which encodes lba-1), CD68, PTGS2 (which encodes COX2), GFAP, IL1 $\beta, I L 6, I L 10$, and TNF- $\alpha$ in the locus at Braak stages I, II, II, and IV, and in middle-aged individuals with no NFT pathology. Expression values for the distinct probes are normalized with combined mean values of AARS, GUS- $\beta, H P R T 1$, and XPNPEP1. AD cases analyzed are the same as those used in whole-transcriptome arrays. Mean fold-change values for each group were compared with one-way analysis of variance (ANOVA) followed by post-hoc Tukey's multiple comparison test and differences were considered statistically significant at ${ }^{*} p<0.05 ;{ }^{* *} p<0.01$; ${ }^{* *} p<0.001$ compared with MA; $\$ p<0.05 ; \$ \$ p<0.01 ; \$ \$ p<0001$ compared with stage $\mathrm{l} ;$ \& $p<0.05 ; \& \& p<0.01 ; \& \& \& p$ $<0.001$ compared with stage II; and $\sim \mathrm{p}<0.05 ; \sim \mathrm{p}<0.01 ; \sim \sim \mathrm{p}<0.001$ compared with stage III. Tendencies were considered at \# $p<0.1$. Moderate activation of inflammatory responses is manifested by increased AIF1, CD68, PTGS2, IL $\beta, I L 6$, and TNF- $\alpha$ with disease progression. GFAP and IL10 mRNA expression levels are not modified at these stages.

This article is protected by copyright. All rights reserved. 
Fig. 6: Expression of alpha-2A adrenergic receptor $\left(\alpha_{2 A} A R\right)$ and tyrosine hydroxilase $(T H)$ in the hippocampus and amygdala at different Braak stages of NFT pathology. Membrane extracts $(80 \mu \mathrm{g})$ from human hippocampus $(A)$ and amygdala $(B)$ necropsies were analyzed with SDS-PAGE and immunoblotted using a rabbit anti- $\alpha_{2 A} A R$ polyclonal antibody $(1 \mu \mathrm{g} / \mathrm{ml})$, a rabbit anti-TH polyclonal antibody $(1 \mu \mathrm{g} / \mathrm{ml})$, and a rabbit anti- $\alpha$-actinin polyclonal antibody $(1 \mu \mathrm{g} / \mathrm{ml})$. A HRP-conjugated anti-rabbit IgG $(1 / 30,000)$ was used as a secondary antibody. The immunoreactive bands were visualized with chemiluminescence. Two different representative human samples for each group (i.e. middle-aged individuals MA and stages I, II, III, and IV; see Table 1) are shown. Quantification of $\alpha_{2 A} A R$ and $T H$ expression in hippocampus (A) and amygdala (B) membranes are shown in the lower panels. The immunoreactive bands corresponding to $\alpha_{2 A} A R$ and $T H$ in each human sample were normalized with $\alpha$-actinin expression. Data were normalized by the expression of $\alpha_{2 A} A R$ and $\mathrm{TH}$ in the control group \pm SEM of 4 to 10 samples per group (MA $n=10$, stage I $n=8$, stage II $n=4$, stage III $n=6$, stage IV $n=5$; see Table 1 ). One-way analysis of variance (ANOVA) followed by post-hoc Tukey's multiple comparison test were used; differences are considered statistically significant at * $p<0.05$ compared with control; $\$ p<0.05$ and $\$ \$ p<$ 0.01 compared with stage I.

Figure 7: A) Significant gene differences are seen when comparing gene expression profiles in LC at Braak stages I-IV of NFT pathology. Differences between groups are considered statistically significant at un-adjusted $p<0.05$. B) Hierarchical clustering heat map of mRNA array transcripts showing differential gene expression profile in LC at Braak stages I, II, III, and IV of NFT pathology.

Figure 8: mRNA expression levels of SCARNA2, HSPA6, ID4, HSPA1A/B, and DNAJB1 in LC at Braak stages I, II, III, and IV of FNT pathology determined by TaqMan PCR assays. Expression values for the distinct probes were normalized with combined mean values of AARS, GUS- $\beta$, HPRT1, and XPNPEP1. Cases analyzed are the same as those used in whole-transcriptome arrays. Mean fold-change values of each group were compared with one-way analysis of variance (ANOVA) followed by post-hoc Tukey's multiple comparison test and differences are considered statistically significant at ${ }^{*} p<0.05 ;{ }^{* *} p<0.01 ;{ }^{* * *} p<$ 0.001 compared with MA; $\$ p<0.05 ; \$ \$ p<0.01 ; \$ \$ p<0001$ compared with stage I; \& $p$ $<0.05 ; \& \& p<0.01 ; \& \& \& p<0.001$ compared with stage II; and $\sim p<0.05 ; \sim p<0.01 ; \sim \sim$ $p<0.001$ compared with stage III. Tendencies are considered at $\# p<0.1$.

This article is protected by copyright. All rights reserved. 
Supplementary figure 1: Immunoblot detection of human $\alpha_{2 A}-A R$ expressed in HEK-293T cells. HEK-293T cells were transiently transfected with cDNA encoding the $\alpha_{2 A}$-AR or empty pcDNA3.1+ vector (mock). Increasing concentrations $(1,2$, and $3 \mu \mathrm{g})$ of cell membrane extracts were analyzed with SDS-PAGE and immunoblotted using a rabbit anti- $\alpha_{2 A}-A R$ polyclonal antibody $(1 \mu \mathrm{g} / \mathrm{ml})$. A HRP-conjugated anti-rabbit IgG $(1 / 30,000)$ was used as a secondary antibody. The immunoreactive bands were visualized with chemiluminescence.

Supplementary figure 2: A) IPA analysis of top altered networks in LC and network-related diseases and biofunctions comparing Braak stage IV with stage I of NFT pathology. B) Interaction diagram of altered pathways.

A

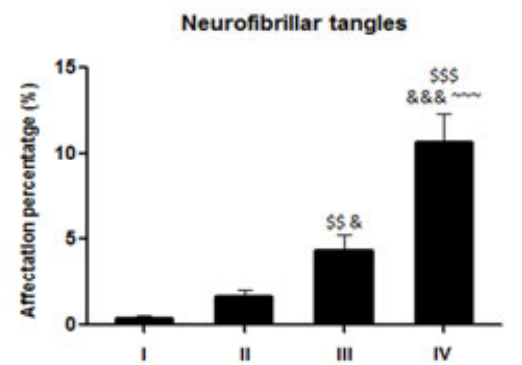

B c
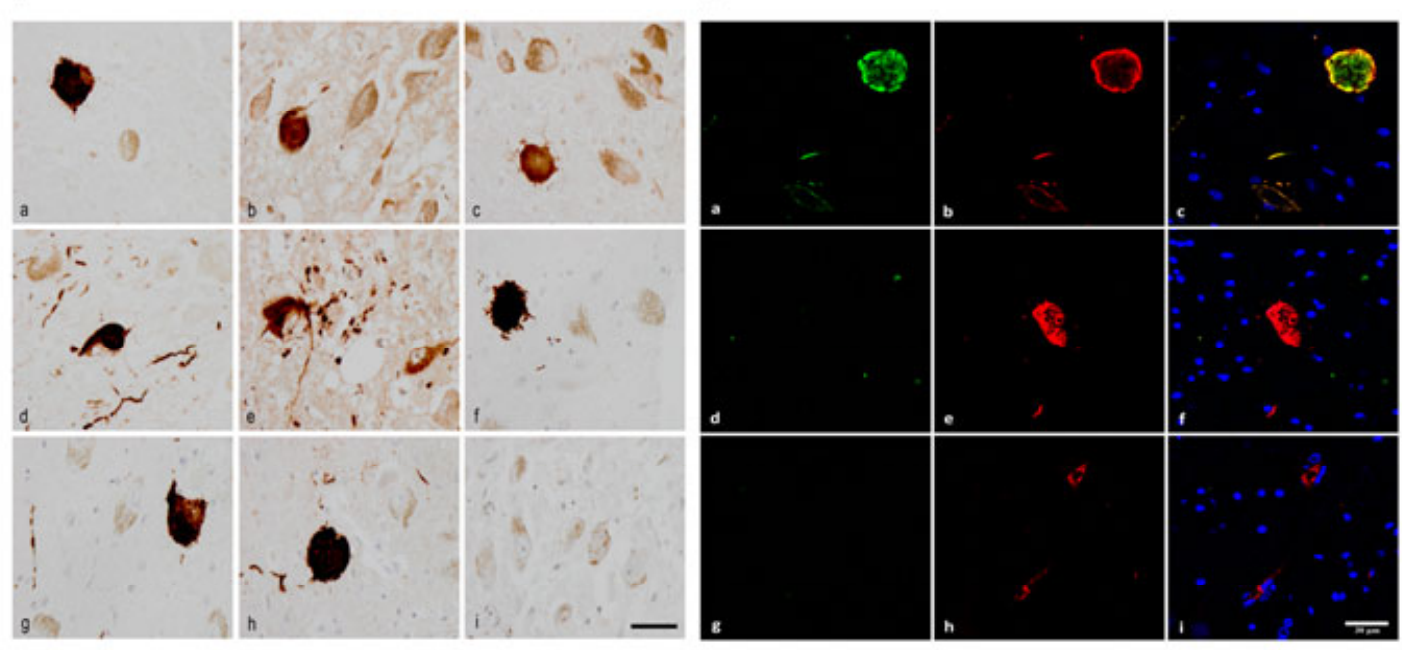

This article is protected by copyright. All rights reserved. 


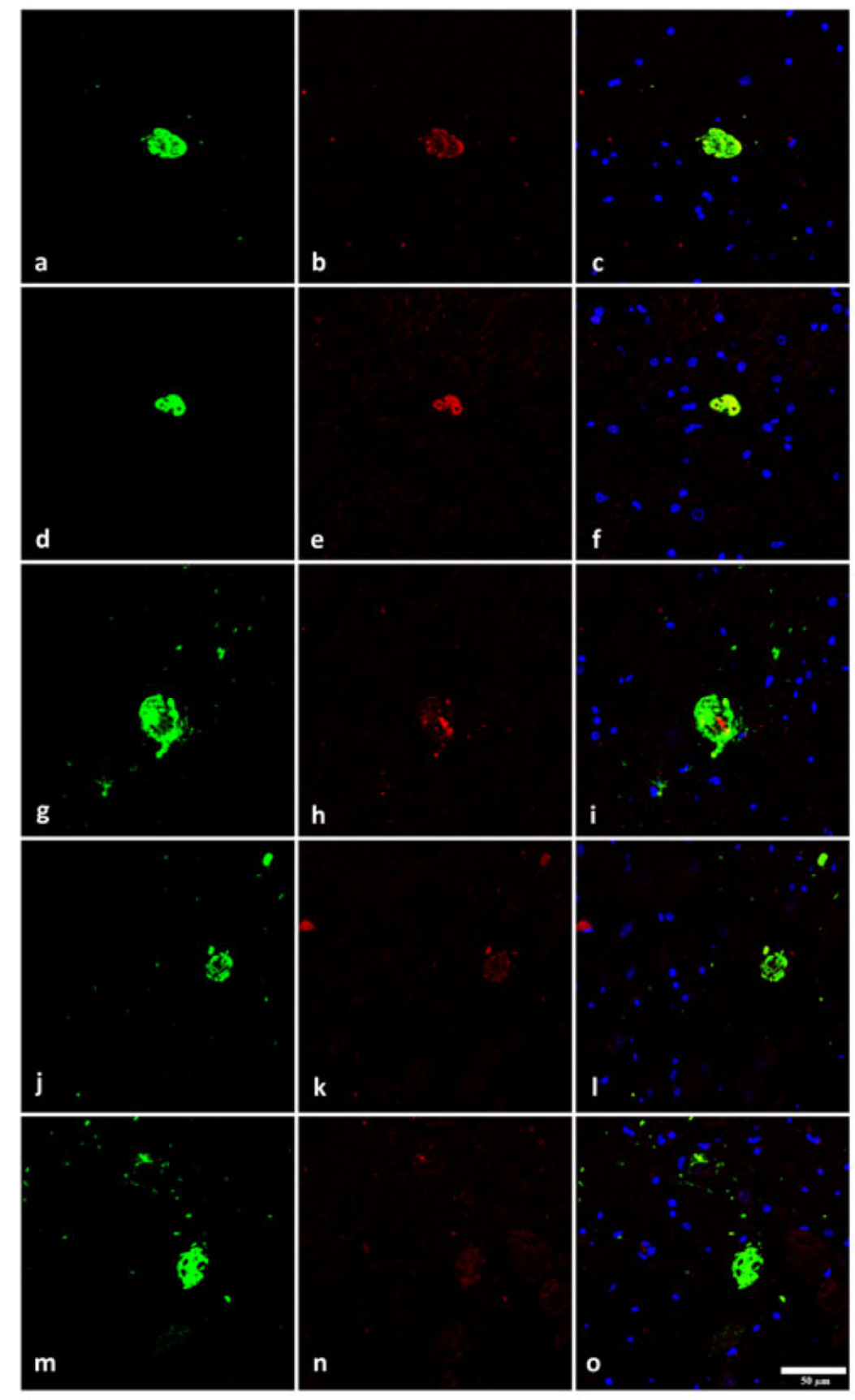

This article is protected by copyright. All rights reserved. 
A

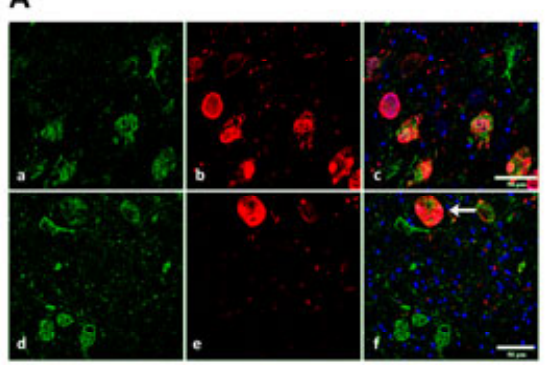

c

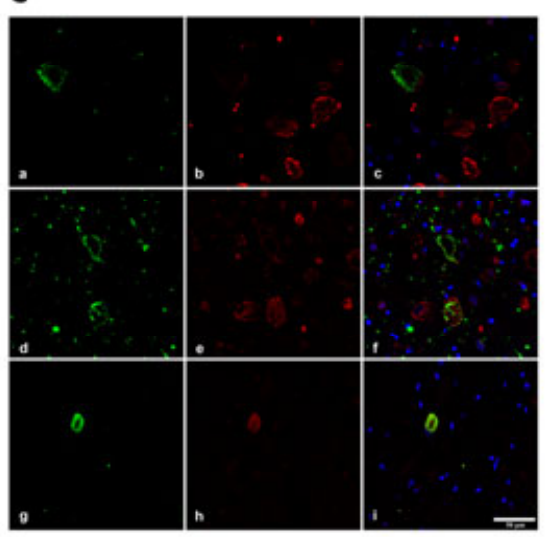

B

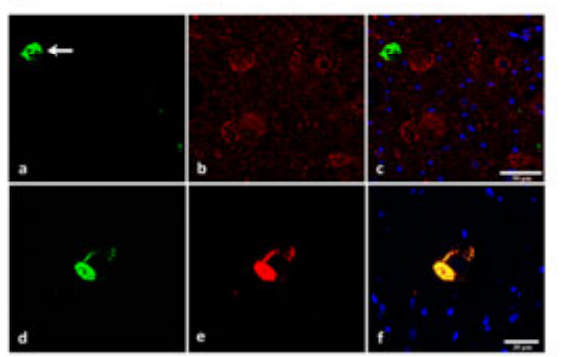

. 
A

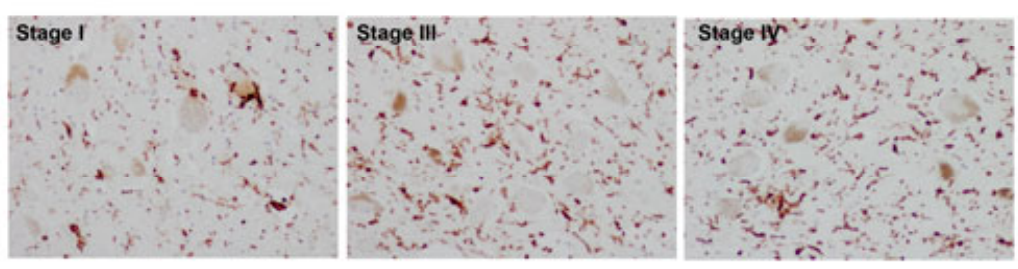

B

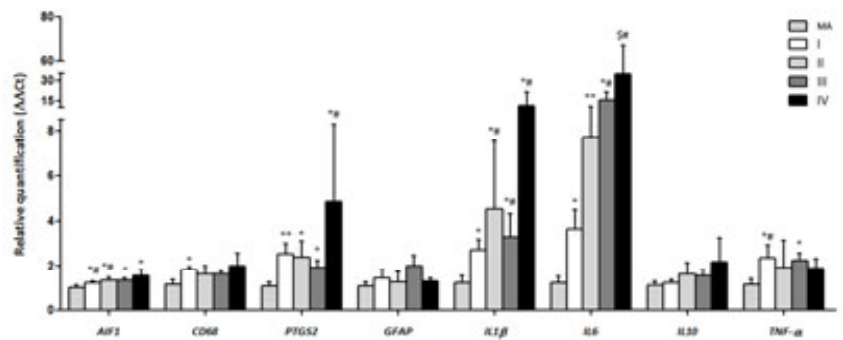

A
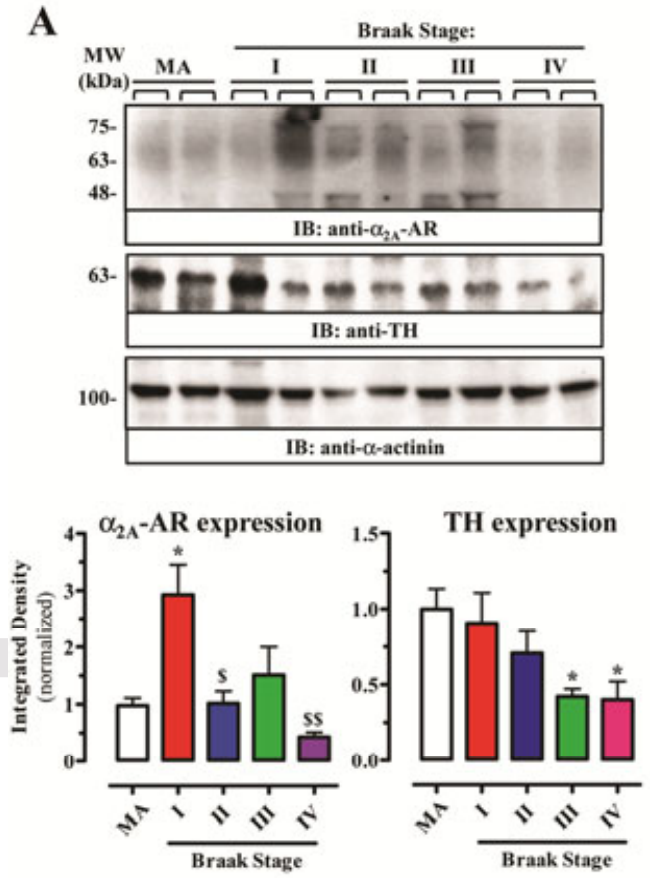

B
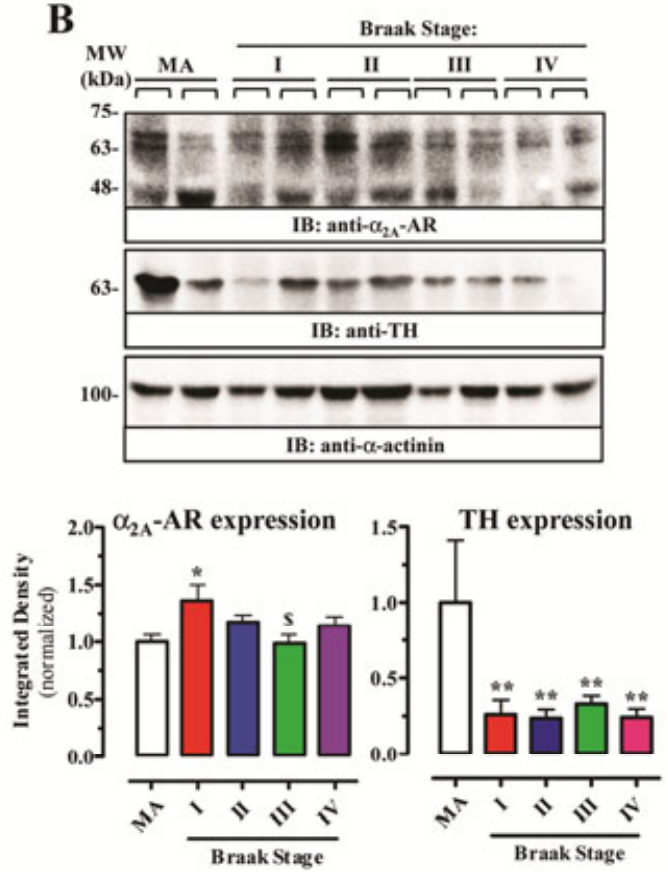

This article is protected by copyright. All rights reserved. 


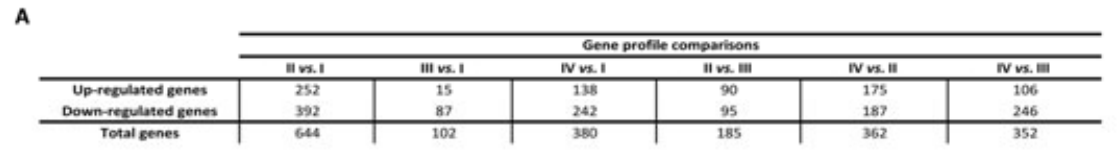

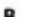
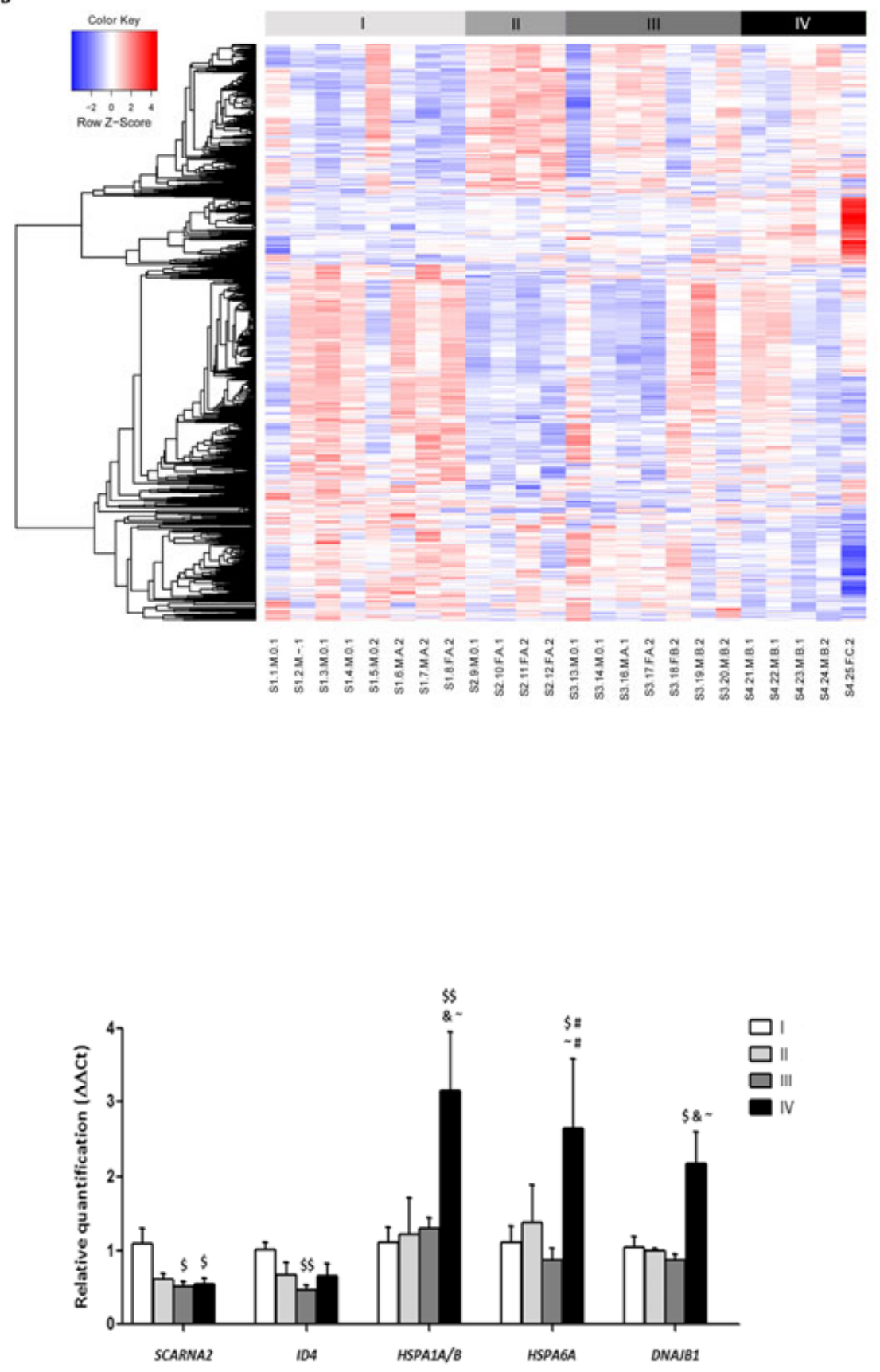

This article is protected by copyright. All rights reserved. 